\title{
DISCURSIVE CONSTRUCTION OF POWER IN STUDENTS' ANONYMOUS FEEDBACK
}

\author{
Nguyen Thi Thu Ha*, Nguyen Huong Giang, Vu Minh Huyen \\ Faculty of Linguistics and Cultures of English-speaking Countries, \\ VNU University of Languages and International Studies, \\ Pham Van Dong, Cau Giay, Hanoi, Vietnam
}

Received 05 March 2017

Revised 05 May 2017; Accepted 18 May 2017

\begin{abstract}
This study was conducted on more than 400 negative anonymous comments, in which students convey some complaint or express discontent about their teachers. The study takes a poststructruralist approach to discourse analysis, positioning that power is contructed and negotiated through discourse (Foucault, 1972; Fairclough, 2010; Mills, 1997). The study aims to find out how students actually do their power through linguistic choices by looking at some pragmatic aspects such as speech acts, addressing terms and politeness strategies (Yule, 1996). The study found that students explicitly do power in this discourse; besides, negotiation of traditional roles was also present. This reflects the complexity of the teachers - students power relation in a comtemporary Vietnam, in which there exist both market economy's definition of education and traditional perception of teaching and learning. ${ }^{1}$
\end{abstract}

Keywords: anonymous feedback, discursive construction of power, poststructuralism

\section{Introduction}

In light of post-structuralist discourse analysis theory, this article examines an aspect of the power relation between teachers and learners in the context of contemporary Vietnam. In particular, it critically looks into the discourse of anonymous feedback given by students on their university lecturers. This social practice gives students the chance to evaluate their lecturers' performance and express their opinions concerning what should be improved in the lecturers' teaching. The practice itself reflects a change in the view of teacher - learner relationship in the education setting whereby students are made active

\footnotetext{
* Corresponding author. Tel.: 84-903266696

Email: thuha2615@gmail.com

${ }^{1}$ This research was completed with the financial support from the University of Languages and International studies - VNU in the project N16.02.
}

participants in education, who have their voices to be heard and issues to be addressed. More importantly, anonymity gives students the chance to honestly "speak up" without fearing about the possible consequences of creating bad impressions on themselves. These comments later can be accessed by heads of departments and the teachers; however, while the Dean can read comments on all department staff, each teacher can only receive the comments on their own teaching, not those comments for their colleagues'. This arrangement eliminates unnecessary spread of reputation, but at the same time guarantees that the comments are well received. In the context where the data for this study were gathered, students are required to give anonymous feedback every two semesters on an online platform in which they will assess their teachers' teaching by giving them a score from 1 to 5 to each of the categories given and leave 
their written comments underneath the scoring tables. This practice has been implemented in the university for about ten years and has shown its strengths, a prominent of which is that teachers can have a reference about how well they are performing, from students' perspective, comparing to their co-teachers and to their colleagues across the departments. Also, without this practice, there seem to be no comments from the students just because direct feedback in any forms is rare.

The data of the study consist of 462 comments of students in which negative feedback rather than positive feedback is found. These comments are numbered from C1 to C462 for reference. Negative feedback in this study is understood as feedback in which students express their dissatisfaction about the teachers' performance and/or behaviors, which are believed to hinder students' learning or their motivation to learn. In other words, in these negative comments, at least one complaint is found about the teachers themselves or their teaching.

In the existing literature, complaints have been of interest of numerous studies in the domains of pragmatics and discourse analysis; however, none has been done from a CDA perspective to shed light on a social issue like the current study. For example, Chen (2011) focused on the strategies used in American and Chinese complaints from a cross-cultural perspective; Heinemann (2009) was interested in the participation and exclusion in third party complaints by looking at video - recorded data in Spanish and Selting (2012) looked into a corpus of audio and video recordings of German everyday private telephone conversations between friends in colloquial in order to find out the complaint stories and subsequent complaint stories with affect display. Apparently, a study on complaints from CDA perspective using pragmatic frameworks is worth carrying out.

\section{Contextual background}

Official education in Vietnam dated back to the $11^{\text {th }}$ century during the feudal time, and one of the traditional values of the Vietnamese people is promotion of learning and high respect for teachers. Teachers' position was perceived even higher than that of parents and only lower than the king's. Teachers were believed to be the ones who taught children how to become "human beings". This stresses the crucial role of teachers in the traditional ideology of Confucianism-oriented education. It is important to note that, Confucius is until now an influential figure in the culturalspiritual life of the Vietnamese; hence, even though education in Vietnam has gone through different political regimes of French colony and Vietnamese communism, the Confucian ideals of teaching and learning still remain. Take for example the Literature Temple where Confucius is worshipped. Every New Year occasion, people, especially children, rush there to pray and spiritually ask for good luck in study. Moreover, as a matter of fact, teachers are prevalently treated with respects by not only learners but also learners' parents.

However, it is essential to note that the current society of Vietnam, since the open door policy in 1986, has been undergoing far reaching changes in all aspects of life, and education is not an exception. The national reform to move from the centralized planning system to socialist oriented market mechanism entails broad reforms in education sector. One of the essential issues is that schooling is no longer solely state-owned and subsidized; but more options are introduced into the schooling system, to include private kindergartens, semi-public and people founded institutions at all levels. Recently, international schools, and international affiliate programs are also among the education options. This perfectly aligns with the trend in the world, whereby education is conceptualized more 
as a 'service industry' in which learners are the customers and institutions are service providers. Teaching is a job just like any other jobs and teachers will get paid according to their qualifications and performance. They have certain responsibilities to fulfill just like any other employed people. Take Singapore as an example. A big university in Singapore perceive themselves as "a knowledge enterprise" and their teachers are strictly evaluated by students every semester. The evaluation result is calculated into the decision whether to continue or to terminate their working contracts.

The changes in education aligning to market economy as discussed above certainly affect the perception of education in general and the power relation between teachers and learners in particular. The position of the teacher may not be seen as high as in the feudal ideology of education, which is believed to be outdated in this $21^{\text {st }}$ century. Apparently, the social structure concerning education has changed, and this change will shape and be shaped by discourse in education setting. In the current study, we look at the discourse of anonymous feedback to see how the power relation between teachers and learners is discursively constructed. Although the data were taken from a state owned university, we believe that market economy ideology of education can be found in all corners of life and not just in private educational institutions; however, admissibly, it might be more prevalent and profound in such private schooling.

\section{Post-structuralist approach to discourse analysis}

The 1970s saw the marriage of discourse analysis and social theory of discourse (Foucault, 1972); whereby, discourse is not seen and analyzed purely from a linguistic perspective only. Rather, post-structuralist theorists see discourse as social practice through which social realities are constructed and reflected (Fairclough, 2001). This approach to language analysis was first named Critical Linguistics and later became Critical Discourse Analysis (CDA). One of the main principles of critical discourse analysis is that power relations are negotiated and performed through discourse (Fairclough \& Wodak, 1997). People may be perceived as having more power than others before discourse; however, it is in discourse that people choose to do power or not. In that sense, power is actually performed and constructed through participation in discourse rather than something fixed which is simply reflected in discourse. Power and power relations are hence discursively constructed and maintained or reshaped and brought forward as pre-assumption of upcoming discourse. In that sense, power before discourse can be seen as the result of power construction of previous discourse. The power relation in question in this study is the one between teachers and learners in the context of Vietnam. In the discourse of anonymous feedback, power is seen as presumably given to learners; however, whether they choose to perform power or not is constrained or supported by social assumptions of power dominance, which was discussed in the contextual background. The aim of the research is, hence, to find out whether students enact their power in this discourse, and if yes, then through which linguistic choices they do so.

\section{Pragmatic frameworks in critical discourse analysis}

This study takes a pragmatic approach to the analysis of the discourse in question. To be more specific, some pragmatic frameworks are used in data analysis, which has been 
rarely seen in CDA. According to Fairclough (1989), speakers/writers are not usually free to manipulate language to achieve their goals, but they are constrained by social conventions. In other words, while choosing language to fulfill their aims in communication as claimed by pragmatics theorists, the speakers/writers at the same time reflect and construct social conventions, in which power relation is just one aspect. In communication, the positioning of participants is determinant and at the same time determinative of power ranking of people involved. Positioning (Harré, 2012) can be understood as perceiving who you are and what relation you are in with the person you are communicating with. In other words, positioning means "how people use words (and discourse of all types) to locate themselves and others" (Moghaddam, and Harré, 2010). This positioning sometimes needs negotiation because the relation between people may be complex. For example, when a young doctor who is talking to an old patient, the doctor will have to negotiate between the role of the one just doing his/her job as a doctor or the role of a young person to a senior. S/He may want to be cold and strict as a doctor; however, s/he may also not be comfortable being cold and strict to an old person of his/her grandmother's age, especially in the cultural context of Vietnam. In this case, s/he may find a neutral way which satisfies himself/herself to some degree, and this is called negotiation of roles or position.

The study chooses to look at the choice of speech acts, the choice of addressing terms and the choice of politeness strategies in performing the Face Threatening Acts (FTA) of complaining (Yule, 1996). According to Yule (1996), speech act theory states that people actually do things when they speak and speech acts can be categorized into directives, representatives, commissives, declaratives, and expressives. For convenience of readership, each type will be defined when they are seen throughout findings presentation. The choice of speech acts in giving a negative feedback is believed to convey and construct power on the part of the speakers/writers, which will be further discussed with the data. Addressing terms are also one entry point to decode how power is constructed and reflected. This is a peculiar feature of the Vietnamese language because the choice of addressing terms in Vietnamese bear a lot more than the addressing system of English. According to Luong (1990) and Cooke (1968), addressing terms in Vietnamese varies according to the age of the participants, relationship and status. As far as (social and power) status is concerned, the choice of addressing terms is also believed to reveal much about positioning in the interactions. Besides speech acts and addressing terms, different politeness strategies are also analyzed to answer the question pertaining to discursive construction of power. According to Brown and Levinson (1987), to show our politeness when entering social interactions, we have to acknowledge and show awareness of the face, the public self image, of the people we address. This can be achieved through various means such as indirectness, hedges, or downtoners, etc. Specific terms are defined when they appear during presentation of findings.

With the pragmatic frameworks and CDA approach in mind, we carried out a primarily qualitative analysis of the data; however, quantitative calculation was also utilized at times to back up qualitative interpretations.

\section{Main findings}

\subsection{Students do power through the choice of speech acts}

The most prominent feature noticed through the analysis of speech acts is that in more than half of the comments in question, 
there is a directive. To be specific, there are 304 directives, equivalent to almost $66 \%$ of the comments. Directives are defined as the acts in which the words are aimed at making the listener/ reader do something (Cutting, 2015). This is to show that the students want specific actions from the teachers. The following are just some examples.

(1) Cô giáo nên cho các dạng đề, câu hỏi luận đối với tùng bài ...(C2)

She teacher should provide samples of test and assignment questions for each unit.

(2) Giáo viên cần cho sinh viên thêm tài liệu ôn tập về nhà ... (C13)

The lecturer needs to provide students with revision material to work on at home

Fairclough (1989) supposes that, in communication, it is more often the person in a position of power who can use direct request. Examples can be found in a restaurant between a customer and a waiter, in an office setting between a senior and a junior and even in a family between parents and children. In giving requests on the actions which need to be performed by the teacher, the students are aware of their rights and position themselves as having power.

The choice of modality in many of these directives further supports this argument. Modal "nên" (should) is found in more than $35 \%$ of the directives and "cần" (need) in more than $9 \%$. These are two modals which show a high degree of imposition and necessity on the part of the addressees (Quirk, et al., 1979). The use of these modals apparently constructs students' power in requesting actions from the part of the teacher. Examples (3), (4) and (5) are taken from the data:

(3) cô giáo nên tạo nhiều hoạt động bổ ích hơn nũa... (C452)

She teacher should organize more useful activities ...
(4) giảng viên nên tạo một môi trường học tập vui vẻ, it áp lưc hơn... (C462)

The lecturer should create a more amusing learning environment with less pressure...

(5) giảng viên cần sắp xếp thời gian hoc cao hoc và thời gian đi day hơp lý hơn để sinh viên theo kịp tiến độ chuơng trinh ... (C296)

the lecturer needs to better arrange the time for his/her Master course and teaching time so that students can follow the syllabus timely...

The rest of the directives, not using the above modals, are found to be more indirect with the choice of modals "mong" (expect), "muốn" (want), "mong muốn" (expect), or "hy vọng" (hope) with the subject of these modals being the students, which is sometimes omitted. (6), (7) and (8) are examples:

(6) Em mong muốn được cung cấp nhiều tu liệu hình ảnh hoạc video ngoài hơn nũa (C152)

I expect to be provided with more visual materials or video from other sources.

(7) Hi vọng cô giới thiệu nhiều hơn nũa về tài liệu có ích cho môn họ. (C156)

Hope that you introduce more about useful materials for the subject.

(8) Em muốn cô giáo giải thích bằng Tiếng Việt nhũng khái niệm phức tạp... (C139)

I want you to explain complicated terms in Vietnamese...

Apparently, although these directives are made less direct, they are still requesting for actions to be done. And when the subject is the student in the first personal pronoun, the power is once again explicitly placed on them. The students are the agents of those requests and they are present in the act of requesting.

However, it is also interesting to note a few directives in which the power of the requester is reduced to the minimum. These 
few cases will be discussed later in $5 \mathrm{~d}$ together with other phenomena in which the students choose to maintain in the position of the less powerful.

\subsection{Students do power through the choice of addressing terms}

Addressing terms in Vietnamese are much more diverse and complicated in nature compared to those in English. That is why pragmatic linguists who based their works on English rarely discussed the use of addressing terms as markers of interpersonal relation or power rank between discourse participants. In this study, on the Vietnamese data, we choose to scrutinize the choice of addressing terms and this has revealed a lot of how students do power in anonymous negative feedback.

In the Vietnamese culture, it is common practice to address the teacher as "thầy" (same addressing term for father in the old time) or "cô" (auntie) and to address oneself as "em" (younger siblings) or "chúng em" (plural for younger siblings) in the university or college setting. This practice of addressing presupposes that the relationship between teachers and students are just like that among extended family members and teachers are the seniors while students juniors. In face to face communication, this way of addressing is prevalently found and there is almost no substitute for this.

However, it is noteworthy that in anonymous feedback, there are more diversified choices made in addressing teachers and oneself, which reveals interesting insights.

When addressing the teachers, we found many instances (24\%) of "giáo viên" (teacher) or "giảng viên" (lecturer). These addressing nouns often pair with "sinh viên" (student) when the students refer to themselves. These nouns refer to career title and do not imbed any familial sense or intimacy as in the traditional common practice of addressing mentioned above. The use of those career terms to address the teachers and self positions both the teacher and the student in a professional setting, where they are equal participants, however, with different functions and responsibilities. This gives rise to an interpretation that students see the teacher and themselves at least as having equal power, or they are not less powerful in this relationship. Some examples are given below:

(9) Giáo viên nên cung cấp thêm tài liệu để sinh viên tham khảo và mở rộng kiến thicc. (C5)

Teacher should provide more materials so that students can consult and broaden their knowledge.

(10) Giảng viên chura tạo được sụ gần gũi thân thiện với sinh viên. (C1)

Lecturer has not been able to create rapport with students.

When addressing self, a few comments ( $1 \%$ or 5 in number) use first personal pronoun "tôi" (I, used in detached or formal sense). In reality, this personal pronoun can only be seen in the case (a) the speaker is of higher position, or (b) the speaker is older or (c) the speaker wants to show distance or formality, or (d) the speaker is angry. In face to face communication, if students address themselves as "tôi", it would be disrespectful or at least very weird, regardless of the age of the teacher and the students. The fact that "tôi" is used in anonymous feedback suggests that students are freer in positioning themselves as whatever they want in relation with the teacher. Examples of this addressing form are provided below:

(11) Tôi mong rằng cô giáo sẽ có thêm nhiều phuoong pháp hiệu quả để giúp sinh viên tiến bộ. (C20)

I expect that the teacher will have more effective methods to help students to improve themselves. 
(12) Tôi không cho rằng kĩ năng speaking của cô giáo có thể giúp sinh viên tiến bọ.(C248)

I do not think that the teacher's speaking skills can help students improve.

It is also observed in a few other comments that there lack addressing terms so the comments are like in note forms as in examples (13) and (14). However, these comments are supposed to be read by the teacher in question, so omitting addressing terms altogether may result in less politeness. In the Vietnamese culture, courtesy is greatly important especially when communicating with teachers, who are culturally placed in a higher position.

(13) Thiếu năng động, sáng tạo (C443)

Lacking in dynamics and creativity

(14) Giảng bài kỹ càng, khá thân thiện tuy nhiên chura thưc sụ tạo duợc không khi thoải mái trong lớp (C356)

Thorough explanation, fairly friendly; however, not be able to create a good learning atmosphere

The fact that those comments are lacking in all addressing terms suggests that some students have chosen not to abide by the etiquette rules. They are constructing themselves as being able to set their own rules and exercise the rules in the anonymous feedback practice. While this should not be encouraged, those comments without addressing terms prove that students perceive their power of choice of not going by the expected courtesy rules when communicating with teachers.

\subsection{Students do power through the choice of directness}

As far as politeness is concerned, complaining is a face threatening act, which can be defined as an act that may cause one or both of the interlocutors to lose face. That is why, in performing an FTA, it is common that the speaker will need to choose appropriate strategies to lessen the possibility of someone getting hurt or feeling insulted. As a matter of fact, the more direct these FTA are, the higher the possibility of causing hurt or insults. Hence, indirectness is often the choice when an FTA such as complaints must be performed.

However, in the data of the current research, there is a fair percentage $(31 \%)$ of complaints performed with directness. They are direct in the use of intensifying words, in the explicit use of the complaint target and in absolute negation as well as intensifiers as seen in the following typical examples:

(15) thầy $A B C$ dạy rất buồn ngủ (C26) $\mathrm{Mr}$ teacher $A B C$ 's teaching causes drowsiness.

(16) Thầy nói quá bé nên khó nghe (C31) $\mathrm{Mr}$ teacher speaks too quietly, so difficult to hear him.

(17) Chậm trả bài cho sinh viên, nên sinh viên không biết mình thiếu sót ở đâu để cố gắng tiến bộ. Dạy viết thì quá gò bó với sách. Không khuyến khích tinh thần (C243)

Late in returning assignments so students do not know where they need to improve. Teaching writing is too limited to the course book. (Teacher) does not encourage motivation.

As a matter of fact, in the context of Vietnam, directness is also related to power rank (among other things) in communication. The more powerful one feels, the more direct they tend to be in communication in general and also in giving an FTA. This is because it is more often that the more powerful or the senior have the rights to comment on others rather than the other way round. In the discourse under analysis, in $30 \%$ of the complaints, students choose to be direct in performing an FTA, which proposes that they are in fact doing power. They are explicitly exercising the power of the ones who have the 
rights to give comments on others' work. It is agreeable that giving complaints is already doing power, and giving direct complaints is doing power in emphasis.

\subsection{Students' negotiation of roles}

The points discussed in $5 \mathrm{a}, \mathrm{b}$, and $\mathrm{c}$ clearly support the argument that students in this anonymous feedback practice are doing power through various linguistic choices. They do take advantage of anonymity to construct a new order of power relation in which they can complain, request and even criticize. This is exactly what is meant for them to do when the anonymous feedback practice is implemented.

However, it would be too shallow to be contented with that argument alone, although the argument has been strongly backed up with evidence. Data analysis also reveals that students do not just do their power as mentioned but at the same time, their negotiation of roles is also found. In many instances, students, while doing power, still try to maintain the existing power relation in which they are the lower in the rank and those who need to self-abase and respect their counterpart. It is, however, important to note that doing power and negotiating roles are not found at the same time in all comments but rather the two contending discourses emerges as patterns from the data analysis. There are clear cases of explicitly doing power as discussed in previous sections; however, there are instances where students choose to soften the complaints and maintain as much respect to the teachers as possible.

Indirectness in giving a request is one option used to negotiate roles as in the following examples:

(18) Tuy nhiên, sẽ tốt hơn nếu cô $A B C$ sôi nổi hơn. (C420)

However, it would be better if Ms. ABC is more motivating.
So, rather than just saying "Ms. ABC should be more motivating" like many other direct requests showing power on the part of the student, example (18) is a request in the form of a conditional statement. This is believed to be the softest way of making a request and the student made that choice to eliminate any face threat to the teacher.

In other complaints, different linguistic strategies are used to soften the criticism; hence, the position of students in their more or less traditional roles is defined.

(19) Việc chấm các bài thuyết trình có lẽ chua được phù hơp với tiêu chi thì phải (C106) Presentation marking maybe does not match the set criteria.

(20) Em rất thich sụ tân tưy của cô khi dạy học tuy nhiên nhiều lúc em có cảm giác không khi lớp hoc có phần căng thẳng. (C455)

I very much like her devotion; however, sometimes, I have a feeling that the atmosphere is partly tense.

In (19), agentless nominalization "việc chấm các bài thuyết trình" (presentation marking) seems to direct the complaint to a process or a state of affair and avoid pointing out the person in charge of that process; i.e., who marks the presentation. This navigation of complaint together with tentative markers "có lẽ chưa ... thì phải" makes the complaint less harsh and show a clear perception of power ranking on the part of the students. Much respect is still shown to the person being complained about.

In (20) hedges are found before the actual complaint and this is a common politeness strategy to save the face of the complaint receiver. Not just hedges, other down-toners are also found such as "nhiều lúc" (sometimes), "em có cảm giác" (I have feelings) and "có phần" (partly). When students express that this is just their feelings, it implies that the tenseness of the lesson might be what only they feel and that it should not necessarily be 
a problem to other students. In doing that, the students also take their responsibility in how the lessons are perceived.

Apparently, beside the cases of explicitly doing power as discussed earlier, students are also found negotiating their roles: they are the one who complain; yet, they still want to lower themselves on the power scale by using numerous politeness linguistics strategies to minimize their judgmental power of the evaluators. In other words, while they are evaluating their teachers' work, they seem to still place themselves as learners so there is a certain degree of hesitation or reluctance in giving a complaint.

Throughout the findings as presented, it is prominent that students actually do power and construct their identity as the ones of power in this particular discourse of anonymous feedback. This can be seen to reflect and promote the ideology of market oriented education in which students are no longer submissive to their teachers and passive in the learning process. They are an important component of education and have their rights to speak up for their benefits as customers using a service. However, though not as prevalent, the traditional Confucian assumption on power relation between teachers and learners was also found in students' negotiation of roles. It would be safe to conclude that, in the discourse of anonymous feedback, there exist two contending ideologies that shape the power relation between teachers and students: one of market oriented education and one of traditional schooling, in which the former seem to weigh much more than the later.

\section{Conclusion}

This study has attempted to explore the power relation of learners and teachers in the discourse of anonymous feedback. In particular, the study aimed to find out how students do their power when giving negative feedback or complaints on their teachers and their teachers' teaching. The data were approached from a critical discourse analysis perspective using pragmatic frameworks of speech acts, choice addressing forms and politeness strategies. A prominent finding of the study is that students actually do their power by the choice of direct requests with modality expressing obligatory and necessity in making complaints. They position themselves as the one having power, who evaluate others' work performance. This reflects and at the same time reinforces a market oriented ideology of education whereby learners are customers and the education institutions are service providers. Besides, negotiation of roles was also found, whereby students while giving a complaint attempt to maintain traditional social order in which the teacher is of higher power rank. Negotiation of roles was found through the choice of various politeness strategies.

This study only looked into the complaints or negative feedback given by the students. Further studies may also analyze the positive feedback and it is believed that more on positioning will also be found in compliments. Other aspects of the power relationship between teachers and learners in other discourse may also be of interest in further research.

\section{References}

Brown, P. and Levinson, S. C. (1987). Politeness: Some universals in language usage. Cambridge: Cambridge University Press.

Chen, Y. S. et al. (2011). American and Chinese complaints: Strategies use from a cross-cultural perspective. Pragmatics 8-2, (253-257). DOI: 10.1515/IPRG. 2011.012

Cooke, J. (1968). The Pronominal Reference in Thai, Burmese, and Vietnamese. Berkley: University of California Press.

Cutting, J. (2015). Pragmatics - A resource book for students $\left(3^{\text {rd }}\right.$ ed.). London and New York: Routledge. 
Fairclough, (2010). Discourse and social change (13 ${ }^{\text {th }}$ ed.). Cambridge: Polity.

Fairclough, N. (1989). Language and power. London: Longman.

Fairclough, N. (2001). Language and power ( $2^{\text {nd }}$ ed). London: Longman.

Fairclough, N. and Wodak, R. (1997). Critical Discourse Analysis. In T. Van Dijk (ed.) Discourse studies:A multidisciplinary introduction (pp 258284). London: Sage Publications.

Foucault, M. (1972). The archaeology of knowledge. London: Tavistock Publications.

Harré, R. (2012). Positioning theory: moral dimensions of social-cultural psychology. In Valsiner, J. (ed.) The Oxford Handbook of Culture and Psychology. New York: Oxford University, pp. 191-206.

Heinemann, T. (2009). Participation and exclusion in third party complaints. Journal of Pragmatics 41 (2435 - 2451). DOI: 10.1016/j. pragma.2008.09.044.
Luong, H. V. 1990. Discursive Practices and Linguistic Meanings: The Vietnamese System of Person Reference. Amsterdam: John Benjamins.

Mills, S. (1997). Discourse. London: Routledge.

Moghaddam, F. and Harré, R. (2010) Words, conflicts and political processes. In F. Moghaddam and R. Harré (eds) Words of Conflict, Words of War: How the language weuse in political processes sparks fighting. Santa Barbara, CA: Praeger.

Quirk, R. et al. (1979). A university of English grammar. London: Longman.

Selting, M. (2012). Complaint stories and subsequent complaint stories with affect displays. Journal of Pragmatics 44 (387 415). DOI: 10.1016/j.pragma.2012.01.005

Yule, G. (1996) Pragmatics. Oxford: OUP.

\title{
SINH VIÊN THỰC THI QUYỀN LỰC THÔNG QUA NGỐN NGŨ NHU' THẾ NÀO TRONG PHẢN HỒI KHUYẾT DANH
}

\author{
Nguyễn Thị Thu Hà, Nguyễn Hương Giang, Vũ Minh Huyền \\ Khoa Ngôn ngũu và Văn hóa các nước nói tiếng Anh, Trường Đại học Ngoại ngũu, ĐHQGHN, \\ Phạm Văn Đồng, Cầu Giấy, Hà Nội, Việt Nam
}

Tóm tắt: Nghiên cứu này được thực hiện trên hơn 400 phản hồi khuyết danh của sinh viên mà ở đó, sinh viên thể hiện các khuyến nghị hoặc có nhận xét tiêu cực đối với giáo viên. Nghiên cứu sử dụng đường hướng phân tích diễn ngôn hậu cấu trúc với quan điểm cho rằng quyền lực có thể được kiến tạo và thực thi thông qua diễn ngôn (Foucault, 1972; Fairclough, 2010; Mills, 1997). Nghiên cứu nhằm mục đích tìm ra sinh viên đã thực thi quyền lực của mình như thế nào trong diễn ngôn phản hồi khuyết danh thông qua việc phân tích các khía cạnh ngữ dụng học như hành động lời nói, danh từ nhân xưng, hay chiến thuật lịch sự (Yule, 1996). Nghiên cứu chỉ ra rằng sinh viên đã thực thi quyền lực của mình một cách rõ ràng thông qua các lựa chọn ngôn ngữ; nhưng bên cạnh đó, vẫn còn sự gìn giữ những quan điểm truyền thống giữa thầy và trò. Điều này cho thấy sự phức hợp trong mối quan hệ quyền lực giữa người thầy và người trò trong xã hội Việt Nam hiện tại, ở đó có cái nhìn hiện đại về giáo dục của cơ chế thị trường và quan niệm truyền thống về giáo dục của đạo Khổng.

Từ khóa: quyền lực, phản hồi khuyết danh, phân tích diễn ngôn, hậu cấu trúc 